\title{
Modeling a SERTTA-type vessel using RELAP-7
}

\author{
Joshua Hansel, Ray Berry, David Andrs, \\ Matthias Kunick
}

September 2018

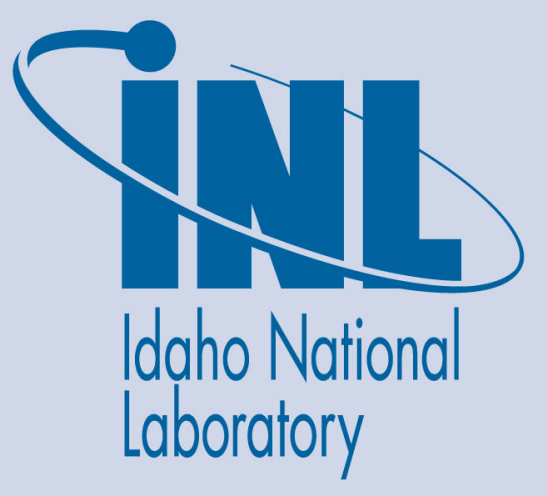

The INL is a U.S. Department of Energy National Laboratory operated by Battelle Energy Alliance 


\title{
Modeling a SERTTA-type vessel using RELAP-7
}

\author{
Joshua Hansel, Ray Berry, David Andrs, Matthias Kunick
}

September 2018

Idaho National Laboratory Idaho Falls, Idaho 83415

http://www.inl.gov

Prepared for the

U.S. Department of Energy

Under DOE Idaho Operations Office

Contract DE-AC07-05ID14517 


\section{Modeling a SERTTA-type vessel using RELAP-7}

Joshua Hansel ${ }^{1}$, Matthias Kunick ${ }^{1}$, Ray Berry ${ }^{1}$, David Andrs ${ }^{1}$, and Richard Martineau $^{1}$

${ }^{1}$ Idaho National Laboratory

September 2018

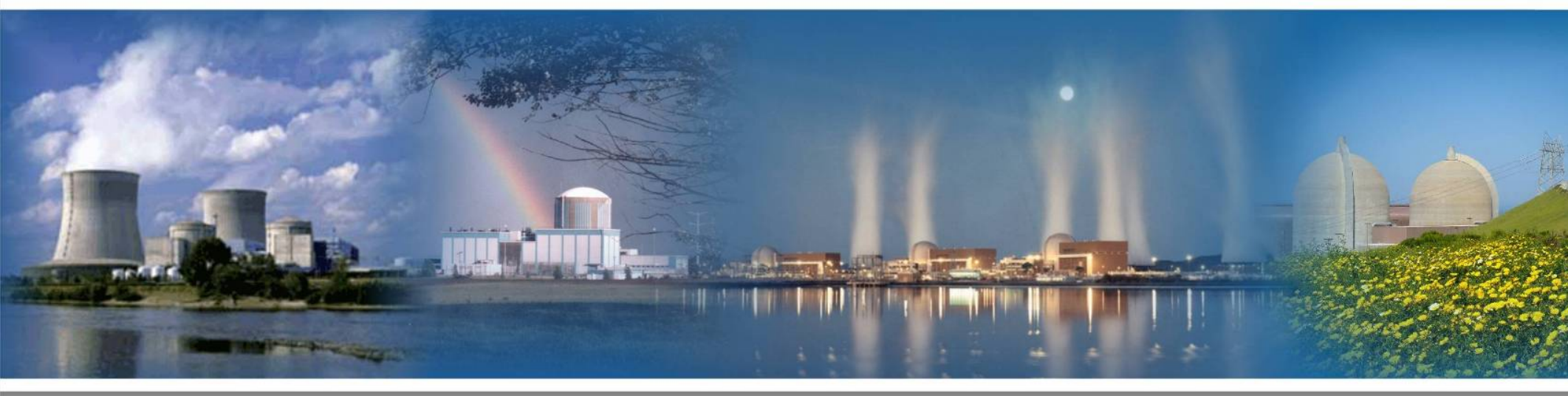

DOE Office of Nuclear Energy 


\section{INL REPORT}

INL/EXT-18-51535

Unlimited Release

Printed September 2018

\section{Modeling a SERTTA-type vessel using RELAP-7}

Joshua Hansel ${ }^{1}$, Matthias Kunick ${ }^{1}$, Ray Berry ${ }^{1}$, David Andrs ${ }^{1}$, and Richard Martineau $^{1}$

${ }^{1}$ Idaho National Laboratory

Prepared by

Idaho National Laboratory

Idaho Falls, Idaho 83415

The Idaho National Laboratory is a multiprogram laboratory operated by

Battelle Energy Alliance for the United States Department of Energy

under DOE Idaho Operations Office. Contract DE-AC07-05ID14517.

Approved for public release; further dissemination unlimited.

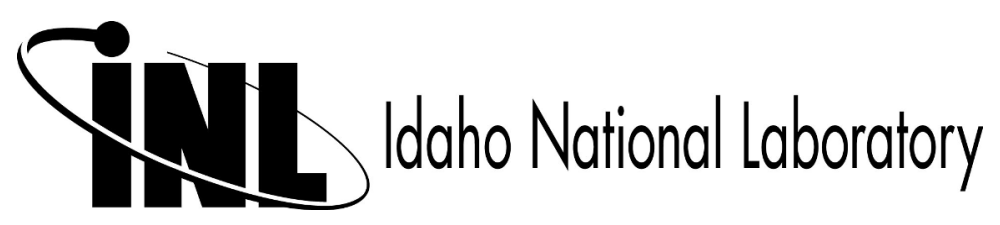


Issued by the Idaho National Laboratory, operated for the United States Department of Energy by Battelle Energy Alliance.

NOTICE: This report was prepared as an account of work sponsored by an agency of the United States Government. Neither the United States Government, nor any agency thereof, nor any of their employees, nor any of their contractors, subcontractors, or their employees, make any warranty, express or implied, or assume any legal liability or responsibility for the accuracy, completeness, or usefulness of any information, apparatus, product, or process disclosed, or represent that its use would not infringe privately owned rights. Reference herein to any specific commercial product, process, or service by trade name, trademark, manufacturer, or otherwise, does not necessarily constitute or imply its endorsement, recommendation, or favoring by the United States Government, any agency thereof, or any of their contractors or subcontractors. The views and opinions expressed herein do not necessarily state or reflect those of the United States Government, any agency thereof, or any of their contractors.

Printed in the United States of America. This report has been reproduced directly from the best available copy.

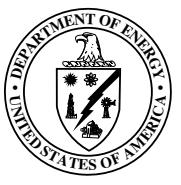


INL/EXT-18-51535

Unlimited Release

Printed September 2018

\title{
Modeling a SERTTA-type vessel using RELAP-7
}

\author{
Joshua Hansel ${ }^{1}$, Matthias Kunick ${ }^{1}$, Ray Berry ${ }^{1}$, David Andrs ${ }^{1}$, and \\ Richard Martineau ${ }^{1}$ \\ ${ }^{1}$ Idaho National Laboratory
}




\section{Contents}

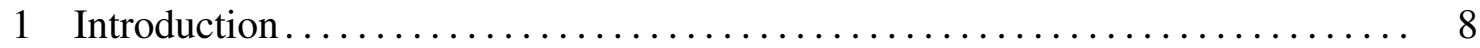

2 Problem Description ........................................ 9

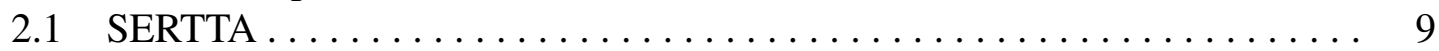

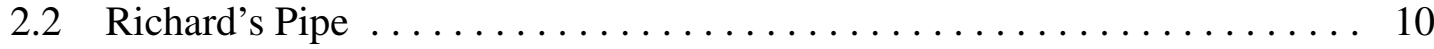

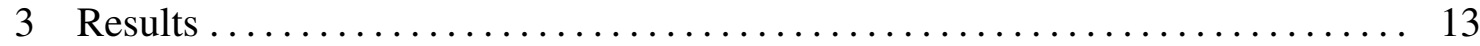

3.1 SERTTA Run 1: Pure Steam in Vapor Region ................. 13

3.2 SERTTA Run 2: Nitrogen/Steam Mixture in Vapor Region ............. 14

3.3 Richard's Pipe ...................................... 17

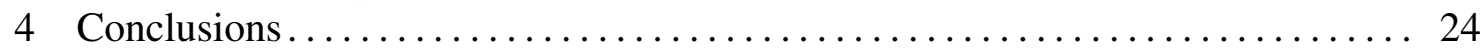

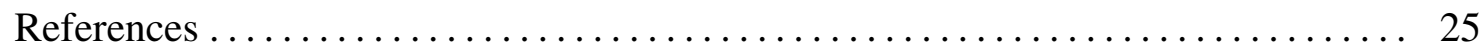




\section{Figures}

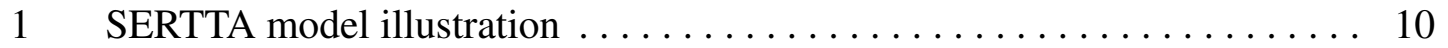

2 Flow area as a function of elevation...................... 12

3 Temperatures at various times for Run $1 \ldots \ldots \ldots \ldots \ldots \ldots \ldots \ldots$

$4 \quad$ Void fraction at various times for Run $1 \ldots \ldots \ldots \ldots \ldots \ldots \ldots \ldots \ldots \ldots$

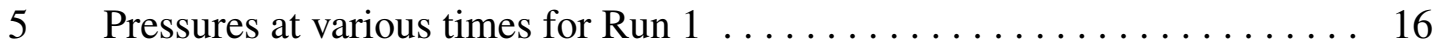

$6 \quad$ Velocities at various times for Run $1 \ldots \ldots \ldots \ldots \ldots \ldots \ldots \ldots \ldots \ldots \ldots$

$7 \quad$ Void fraction at initial and failure time for Run $2 \ldots \ldots \ldots \ldots \ldots \ldots$

$8 \quad$ Nitrogen mass fraction at initial and failure time for Run $2 \ldots \ldots \ldots \ldots 19$

9 Void fraction at various times for Richard's Pipe $\ldots \ldots \ldots \ldots \ldots \ldots .20$

10 Temperatures at various times for Richard's Pipe $\ldots \ldots \ldots \ldots \ldots \ldots \ldots .21$

11 Pressures at various times for Richard's Pipe $\ldots \ldots \ldots \ldots \ldots \ldots \ldots . \ldots \ldots$

12 Velocities at various times for Richard's Pipe $\ldots \ldots \ldots \ldots \ldots \ldots \ldots . \ldots 23$ 


\section{Tables}

1 Original geometrical parameters $\ldots \ldots \ldots \ldots \ldots \ldots \ldots \ldots \ldots \ldots \ldots$

2 Geometrical parameters used in simulation $\ldots \ldots \ldots \ldots \ldots \ldots \ldots \ldots \ldots$

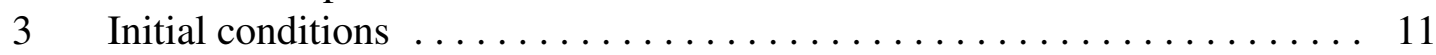

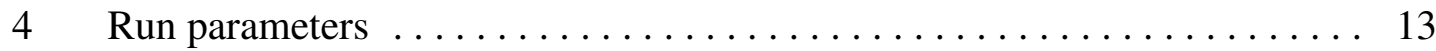




\section{Introduction}

Experiment vehicles, each referred to as a "Static Environment Rodlet Transient Test Apparatus" (SERTTA), were being designed for use in the Transient Reactor Test Facility (TREAT) to test PWR-type fuel specimens. The first of these devices, called MultiSERTTA (MSERTTA), accommodates four rodlets [1]. RELAP-7 seeks to demonstrate the ability to model a transient that could occur in one of these four SERTTA vessels.

A transient in this type of setup should be able to demonstrate a number of different capabilities in RELAP-7, including the following:

- wall boiling,

- volume fraction propagation,

- variable-area flow, and

- non-condensable gases.

The test problems are described in Section 2, results are presented in Section 3, and some conclusions are given in Section 4. 


\section{Problem Description}

\subsection{SERTTA}

From a thermal hydraulic point of view, a single SERTTA unit consists of the main chamber, where the fuel rodlet is located, and a large tank that can collect gases that accumulate in the transient, to avoid the buildup of pressure. Figure 1 gives an illustration of the SERTTA model setup in RELAP-7. The fuel rodlet is submerged (in water) in the region labeled "Heated Region". The water level is between the top of the fuel and the entrance to the expansion chamber, which is filled with vapor. The vapor region consists of a mixture of steam and non-condensable gas(es). This report shows results for 2 test cases:

- Run 1: Vapor region consists of pure steam.

- Run 2: Vapor region initially consists of a mixture of $10 \%$ steam, $90 \%$ Nitrogen, by mass.

The original model dimensions are given in Table 1, and in the RELAP-7 simulation were modified as follows:

- Volume in the expansion tank was redistributed due to insufficient knowledge of the tank curvature profile.

- Total water inventory was increased slightly to allow a nonzero transition layer for void fraction.

The geometrical parameters used in RELAP-7 are summarized in Table 2. Figure 2 shows the flow area as a function of elevation; a cosine function was used to transition between the area values of the main chamber and expansion tank, over a distance of $0.1 \mathrm{~m}$.

Initial conditions are given in Table 3 . The void fraction is varied between the bottom and top values using a cosine function, over a distance of $0.03 \mathrm{~m}$.

The transient is initiated with a prescribed wall temperature in the heated region, which is provided from an output file from a numerical experiment using RELAP5. This wall temperature rises from the initial liquid temperature at $t=0 \mathrm{~s}$ to a maximum of almost $1350 \mathrm{~K}$, around $t=1.2 \mathrm{~s}$, at which point the temperature starts dropping back down. 


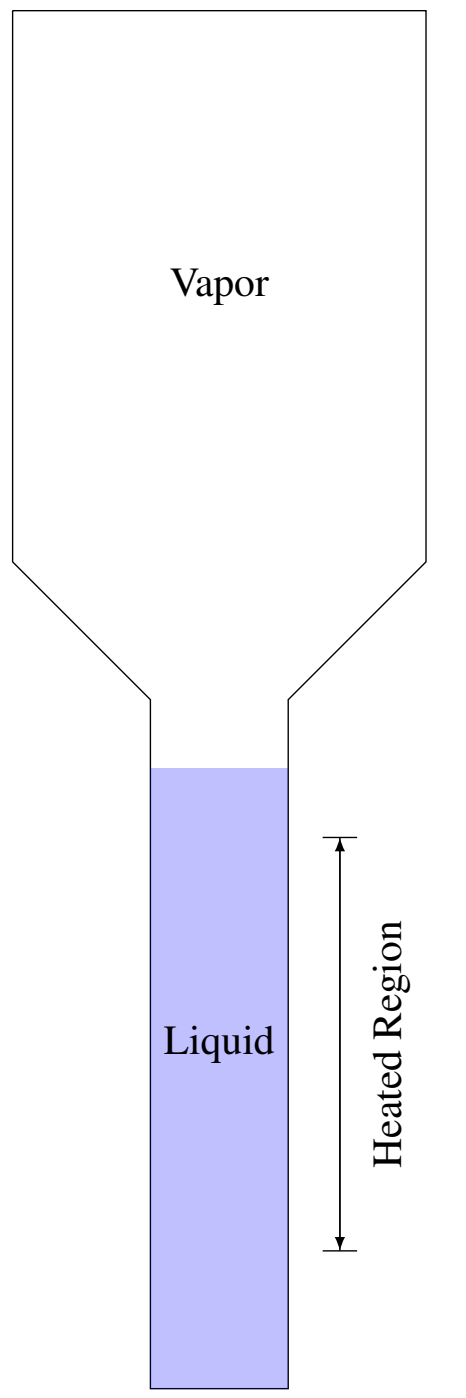

Figure 1. SERTTA model illustration

\subsection{Richard's Pipe}

"Richard's Pipe" is a novel test problem that has plans for a possible experiment for determining interfacial relaxation coefficients. It is included in this report because it includes 
Table 1. Original geometrical parameters

\begin{tabular}{ll}
\hline Parameter & Value \\
\hline Tank main volume & $0.000796272 \mathrm{~m}^{3}$ \\
Tank entrance volume & $0.000142268 \mathrm{~m}^{3}$ \\
Total water volume & $0.000147480 \mathrm{~m}^{3}$ \\
Water volume above heated region & $0.000019652 \mathrm{~m}^{3}$ \\
\hline Tank main volume height & $0.1771904 \mathrm{~m}$ \\
Fuel height & $0.1016 \mathrm{~m}$ \\
\hline Fuel pellet radius & $0.004025 \mathrm{~m}$ \\
Inner clad radius & $0.0041783 \mathrm{~m}$ \\
Outer clad radius & $0.00475 \mathrm{~m}$ \\
Vessel radius & $0.01905 \mathrm{~m}$ \\
\hline
\end{tabular}

Table 2. Geometrical parameters used in simulation

\begin{tabular}{ll}
\hline Parameter & Value \\
\hline Flow area, bottom & $1.069209643722750 \times 10^{-3} \mathrm{~m}^{2}$ \\
Flow area, tank & $3.354544949019616 \times 10^{-3} \mathrm{~m}^{2}$ \\
Heated perimeter in heated region & $2.98451302091030 \times 10^{-2} \mathrm{~m}$ \\
\hline
\end{tabular}

Table 3. Initial conditions

\begin{tabular}{ll}
\hline Parameter & Value \\
\hline Liquid temperature, $T_{\ell}$ & $553.149 \mathrm{~K}$ \\
Vapor temperature, $T_{v}$ & $621 \mathrm{~K}$ \\
Pressures, $p_{\ell}$ and $p_{v}$ & $16 \mathrm{MPa}$ \\
Velocities $u_{\ell}$ and $u_{v}$ & $0 \mathrm{~m} / \mathrm{s}$ \\
Liquid volume fraction, $\alpha_{\ell}$, bottom/top & $0.99 / 0.01$ \\
Vapor volume fraction, $\alpha_{v}$, bottom/top & $0.01 / 0.99$ \\
Nitrogen mass fraction, $\xi_{\mathrm{N}_{2}}$, Run 1/Run 2 & $0.0 / 0.9$ \\
\hline
\end{tabular}

some of the same physical phenomena as the SERTTA problem.

The geometry for this setup consists of a single, vertically-oriented pipe, $2 \mathrm{~cm}$ in diameter, with a length of $1.5 \mathrm{~m}$. The pipe is closed, at the top by a wall, and the bottom by a piston. Before the transient, liquid water is in the bottom of the pipe, with water 


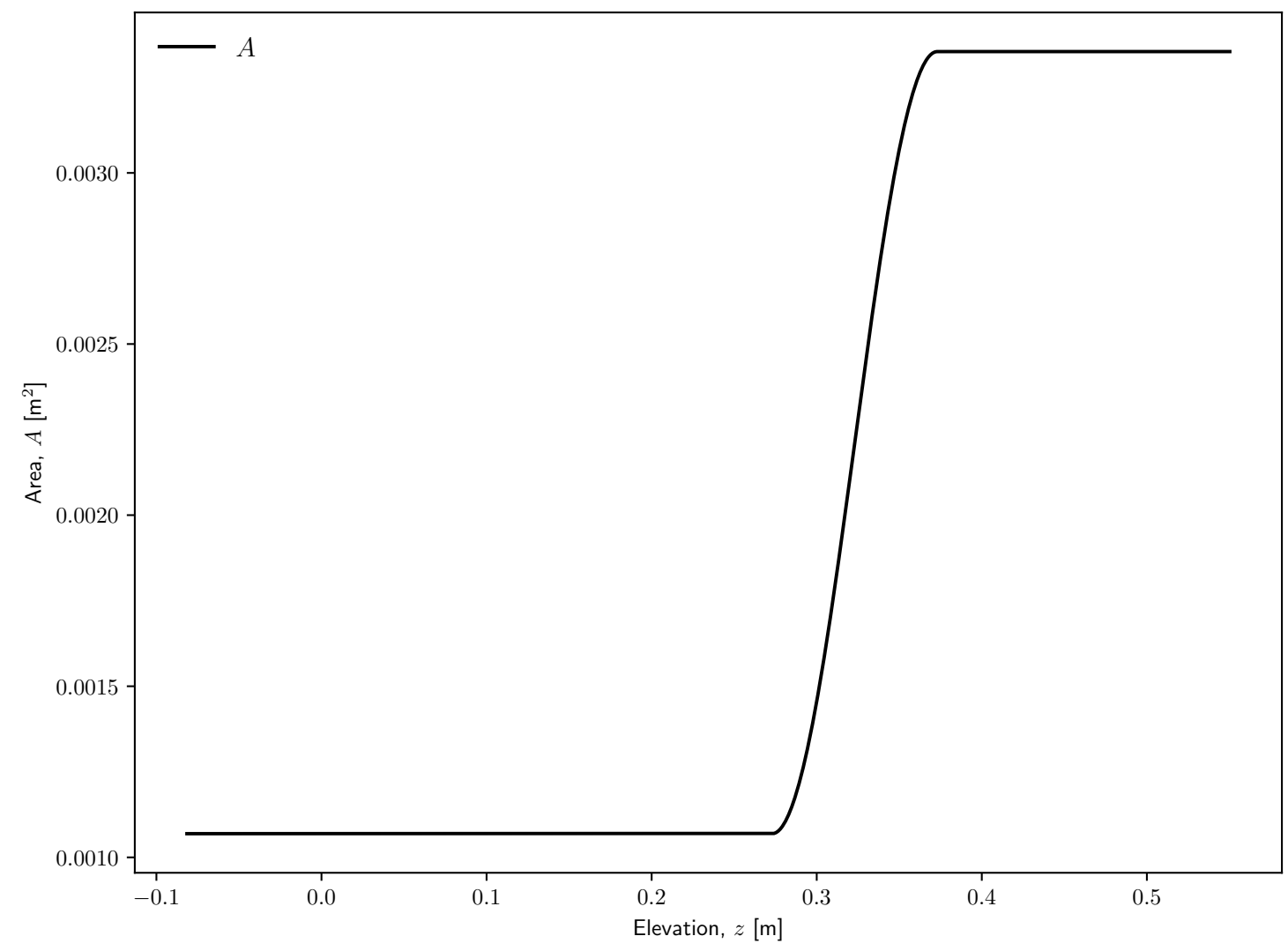

Figure 2. Flow area as a function of elevation

height equal to $1 \mathrm{~m}$. The experimental setup will have the top most likely filled with a non-condensable gas, but for this test problem, steam is used. At the beginning of the transient, the piston moves up with a speed of $10 \mathrm{~m} / \mathrm{s}$, for a total of $0.04 \mathrm{~s}$, by which time the vapor should be compressed to $20 \%$ of its original volume. In RELAP-7 this piston is simulated with an inlet boundary condition; incoming water serves as the "piston". 


\section{Results}

\subsection{SERTTA Run 1: Pure Steam in Vapor Region}

Run parameters are given in Table 4.

Table 4. Run parameters

\begin{tabular}{ll}
\hline Parameter & Value \\
\hline Time integrator & BDF2 \\
Time step size, $\Delta t$ & Adaptive: $10^{-6} \leq \Delta t \leq 10^{-5}$ \\
End time & $1 \mathrm{~s}$ \\
Number of cells & 100 \\
Nonlinear solver & PJFNK \\
\hline
\end{tabular}

The specified wall temperature profile and resulting fluid temperatures are shown in Figure 3. The wall temperature starts at the initial liquid temperature and ramps up to over $1200 \mathrm{~K}$ over the course of the transient. Note that the wall temperature reported outside of the fuel region $(z \in(0.038039468,0.139639468))$ is irrelevant because there is no heat transfer surface outside of this region. Thus wall heat transfer only occurs inside the fuel region. The liquid temperature changes are very small during this transient because the wall temperature quickly rises above the threshold needed for wall boiling, so almost all heat transfer going into the liquid directly goes into vaporization, raising the liquid temperature only slightly. The vapor temperature has a significant increase, due to heat transfer in the fuel region, even with its relatively small volume fraction and wall heat transfer coefficient.

Results for the void fraction are shown in Figure 4. The void fraction plot shows the generation of steam throughout the transient - this is the plateau that rises in the fuel region. As the liquid water heats up and thermally expands, the liquid-vapor interface pushes up toward the expansion tank, along with the vapor generated in the fuel region.

Pressures and velocities are shown in Figures 5 and 6, respectively. As vapor generates through boiling, the pressure builds, since this is a closed system. The velocity profile shows a number of different effects. The left and right ends are fixed at zero due to the top and bottom walls. The liquid profiles show the movement upward due to thermal expansion, with a gradual decrease in the area expansion region. The vapor profiles show 


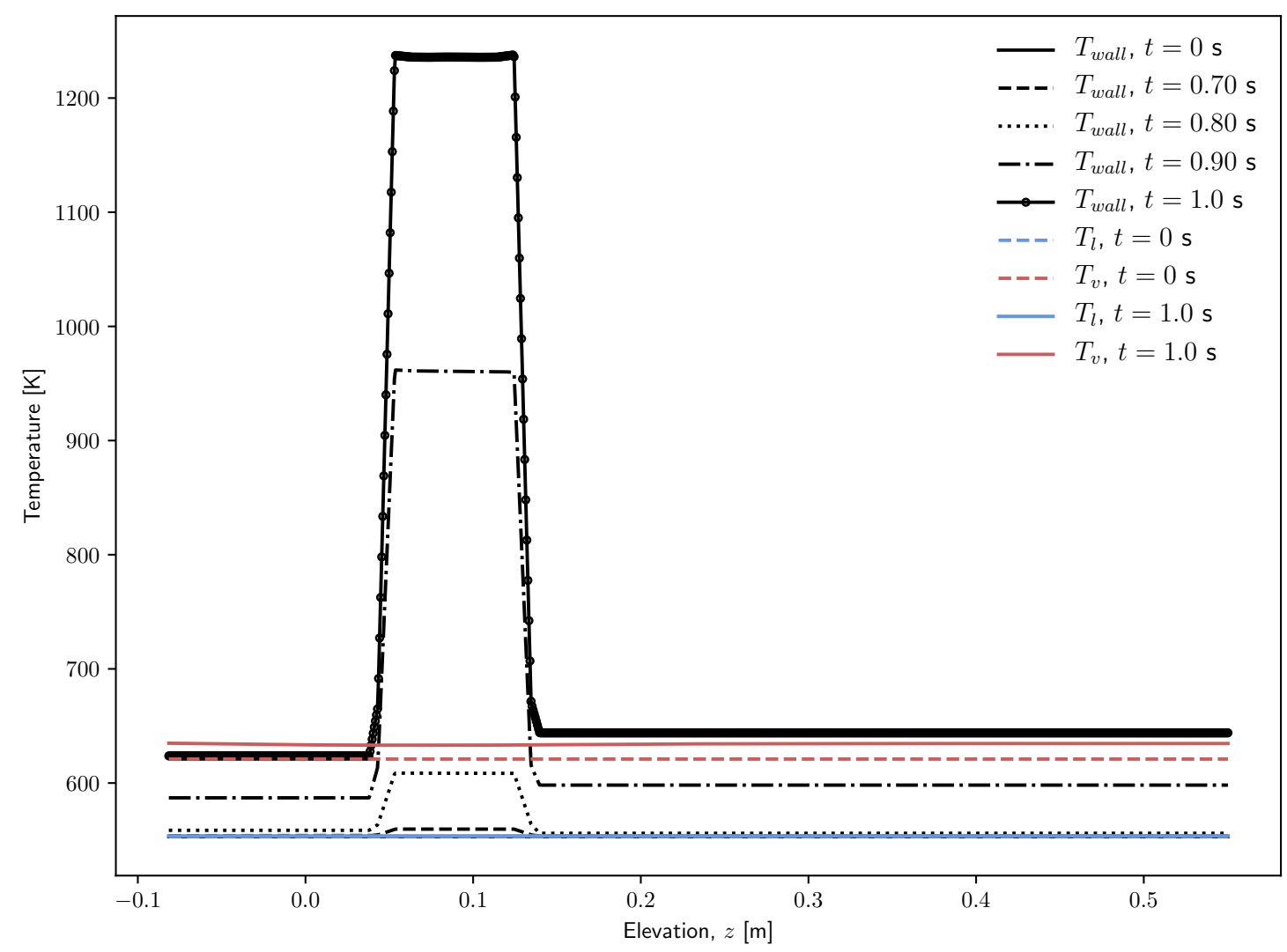

Figure 3. Temperatures at various times for Run 1

vapor moving in both directions from the fuel region, as boiling produces greater vapor pressure in this region, pushing the vapor out of the region. The vapor velocity sharply decreases at the volume fraction interface, due to the much greater volume fraction.

\subsection{SERTTA Run 2: Nitrogen/Steam Mixture in Vapor Region}

The problem setup is the same as in Run 1, except that Nitrogen is in the vapor region, along with steam. All of the run parameters are the same as for Run 1, except that less cells are used; 100 cells are used instead of 1000 cells. This was done simply because currently, 


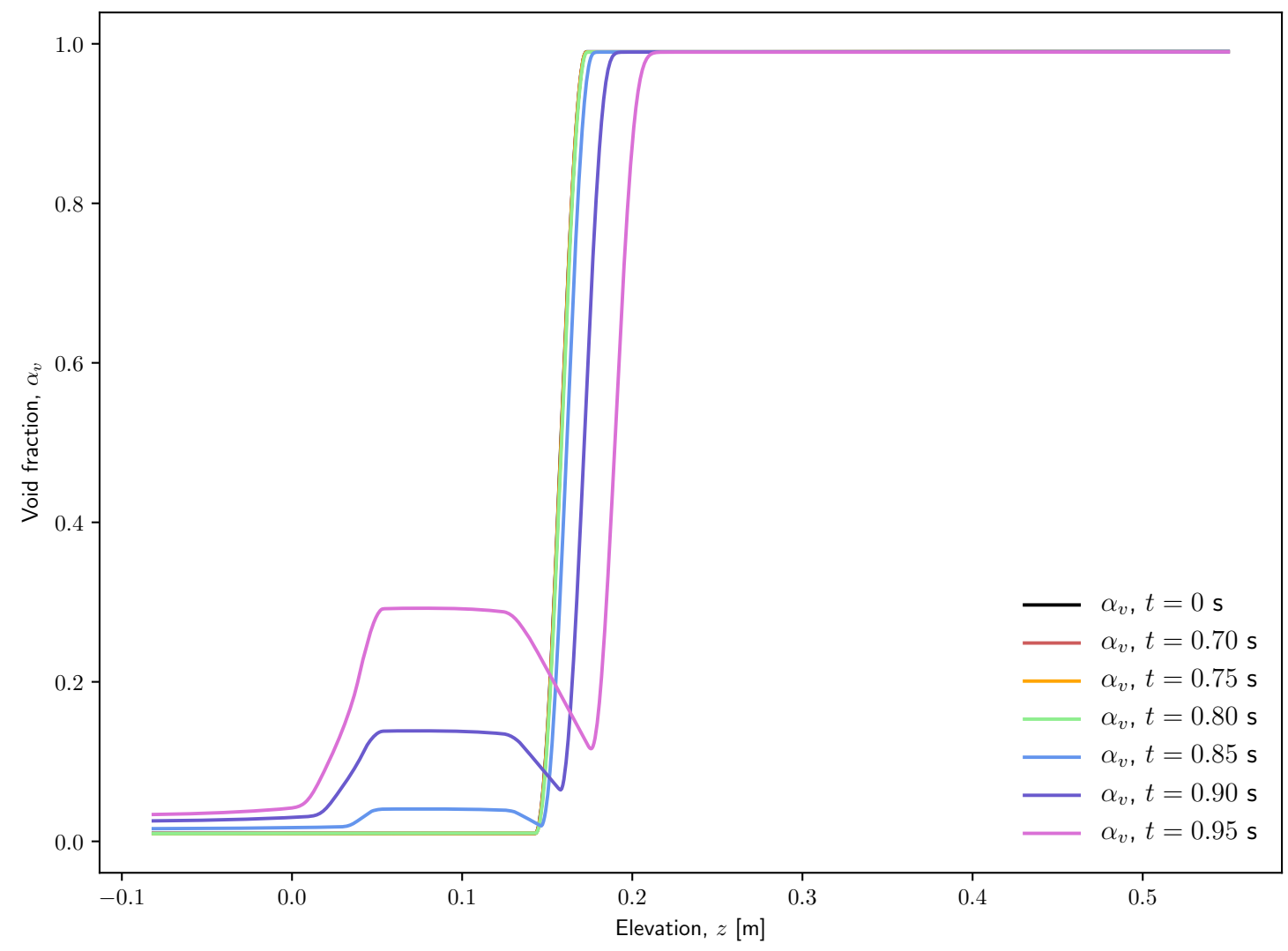

Figure 4. Void fraction at various times for Run 1

the presence of a non-condensable gas in the model increases run time significantly. This is believed to be due to the following factors:

- The nonlinear system size is greater (8 equations vs. 7 equations),

- Iteration is required in some fluid property evaluations in the mixture model, and

- Some Jacobians are still not implemented for the mixture model.

The run fails a short time after the onset of boiling. The ultimate cause of this failure has not yet been identified. A possibility for this could be a failure in iteration in 


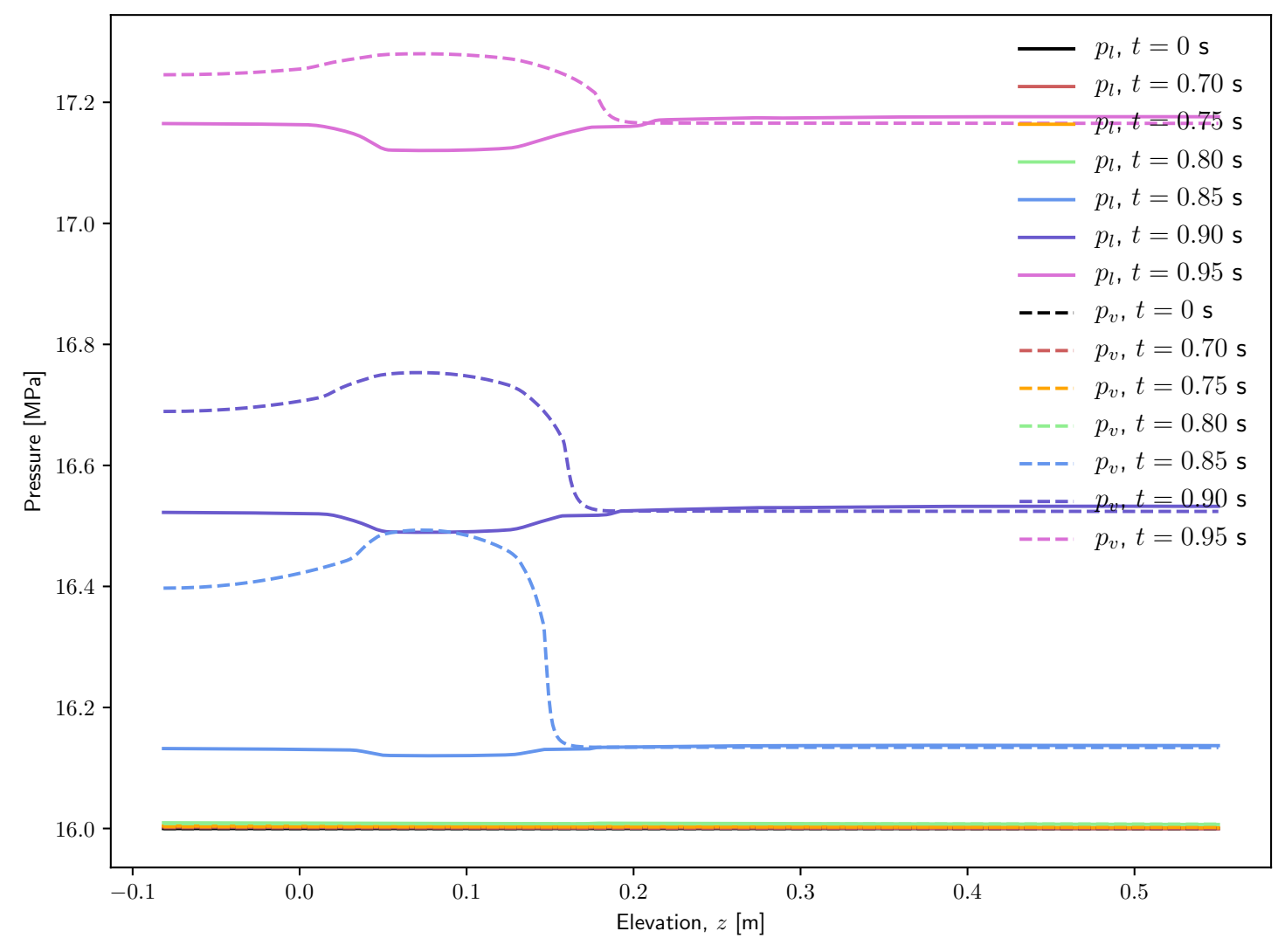

Figure 5. Pressures at various times for Run 1

the mixture model; this mixture model is a fledgling capability in RELAP-7, so some improvements are still likely to be able to be made.

Figures 7 and 8 show the results for void fraction and Nitrogen mass fraction, shortly before failure. The results do at least show the expected trend; the Nitrogen mass fraction decreases in the region of boiling, due to the increasing fraction of steam. Ultimately, boiling rates need to account for the non-condensable gas, but this is a future task. 


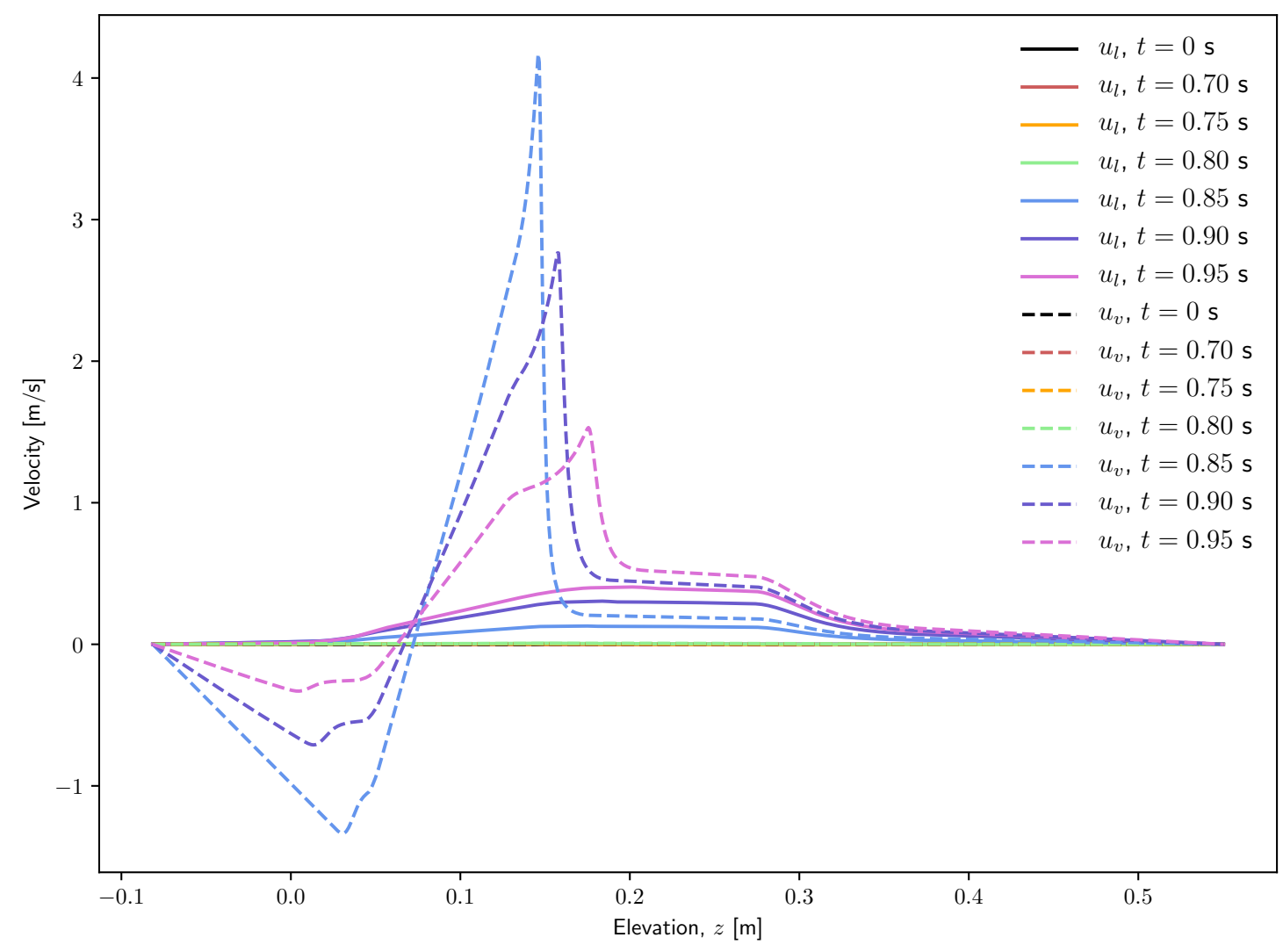

Figure 6. Velocities at various times for Run 1

\subsection{Richard's Pipe}

Figure 9 shows the void fraction profile at points throughout the transient. One can see that the volume fraction interface is moving at the expected rate (the piston speed), and that at the end, the interface is roughly at the expected position of $1.4 \mathrm{~m}$. Discrepancy is mostly due to the artificial dissipation added for stabilization.

Figure 10 shows the temperature results. The liquid temperature stays roughly the same throughout the transient, but the vapor temperature increases as the vapor is compressed, as expected. 


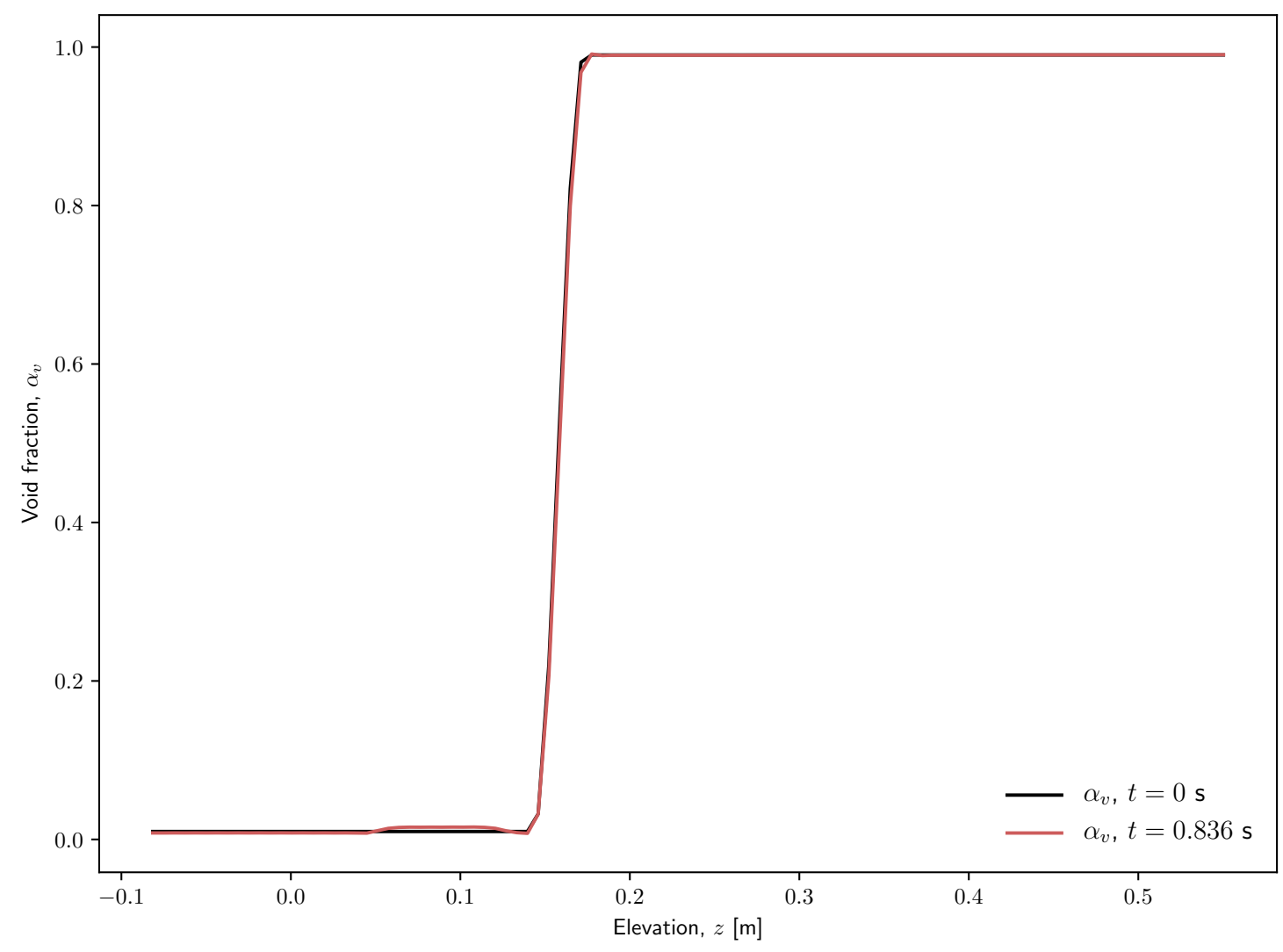

Figure 7. Void fraction at initial and failure time for Run 2

Figures 11 and 12 show the pressure and velocity results, respectively. The pressure in the liquid increases more dramatically than in the vapor as the vapor is compressed, which is believed to be due to the compressibility of the vapor. The velocity shows the expected piston speed of $10 \mathrm{~m} / \mathrm{s}$ for the liquid, whereas the vapor velocity profile shows a large variation throughout the pipe. 


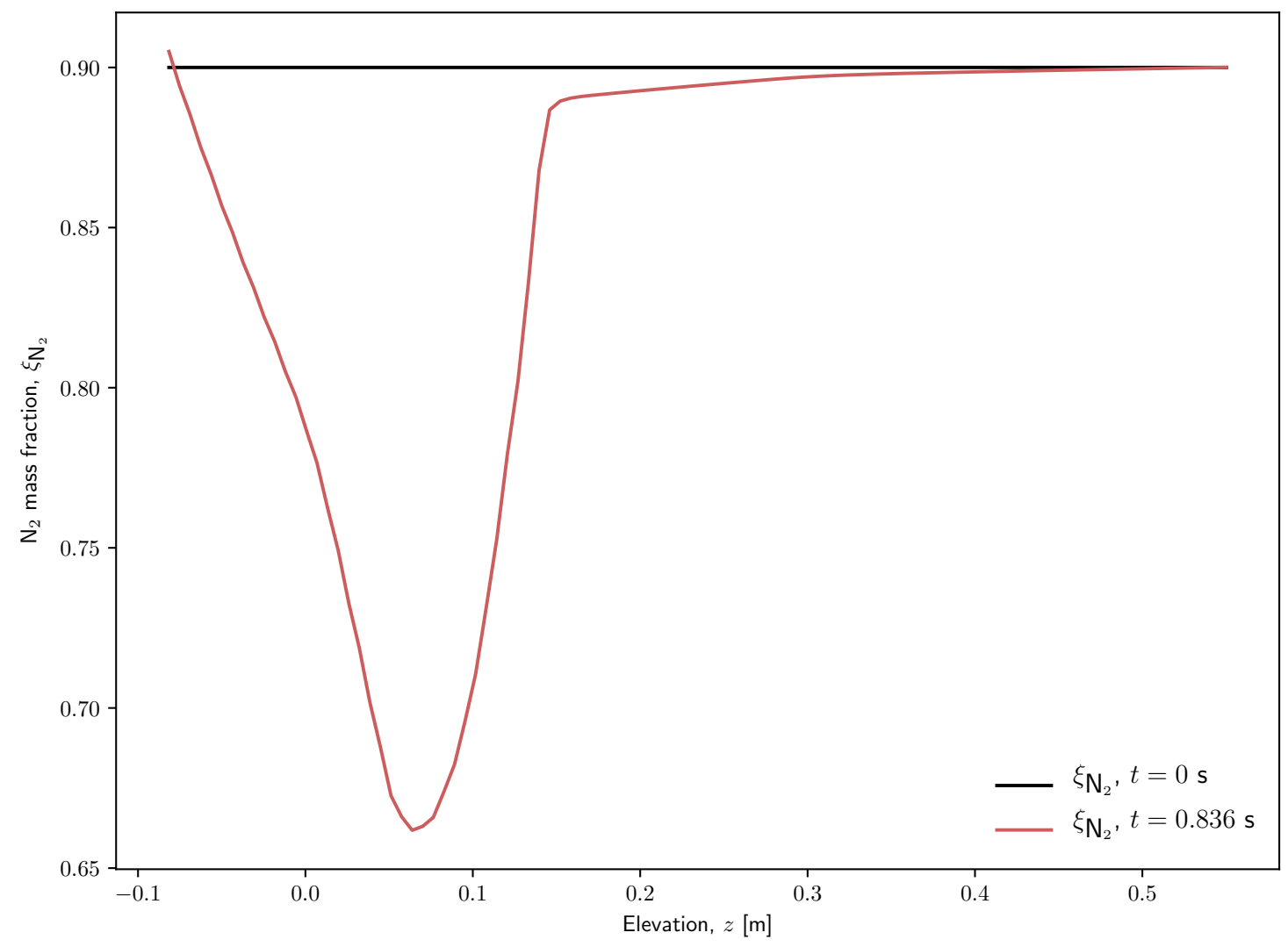

Figure 8. Nitrogen mass fraction at initial and failure time for Run 2 


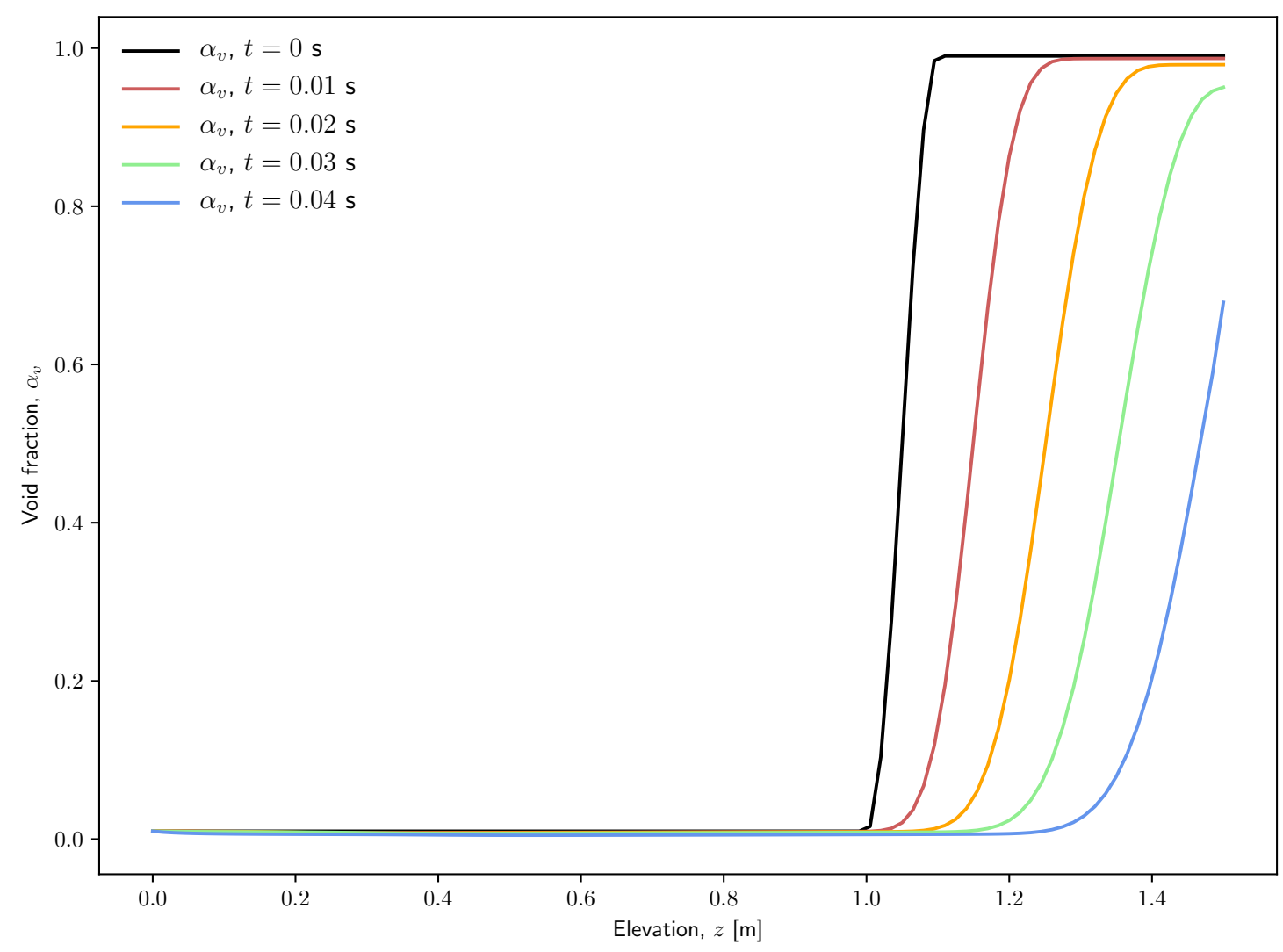

Figure 9. Void fraction at various times for Richard's Pipe 


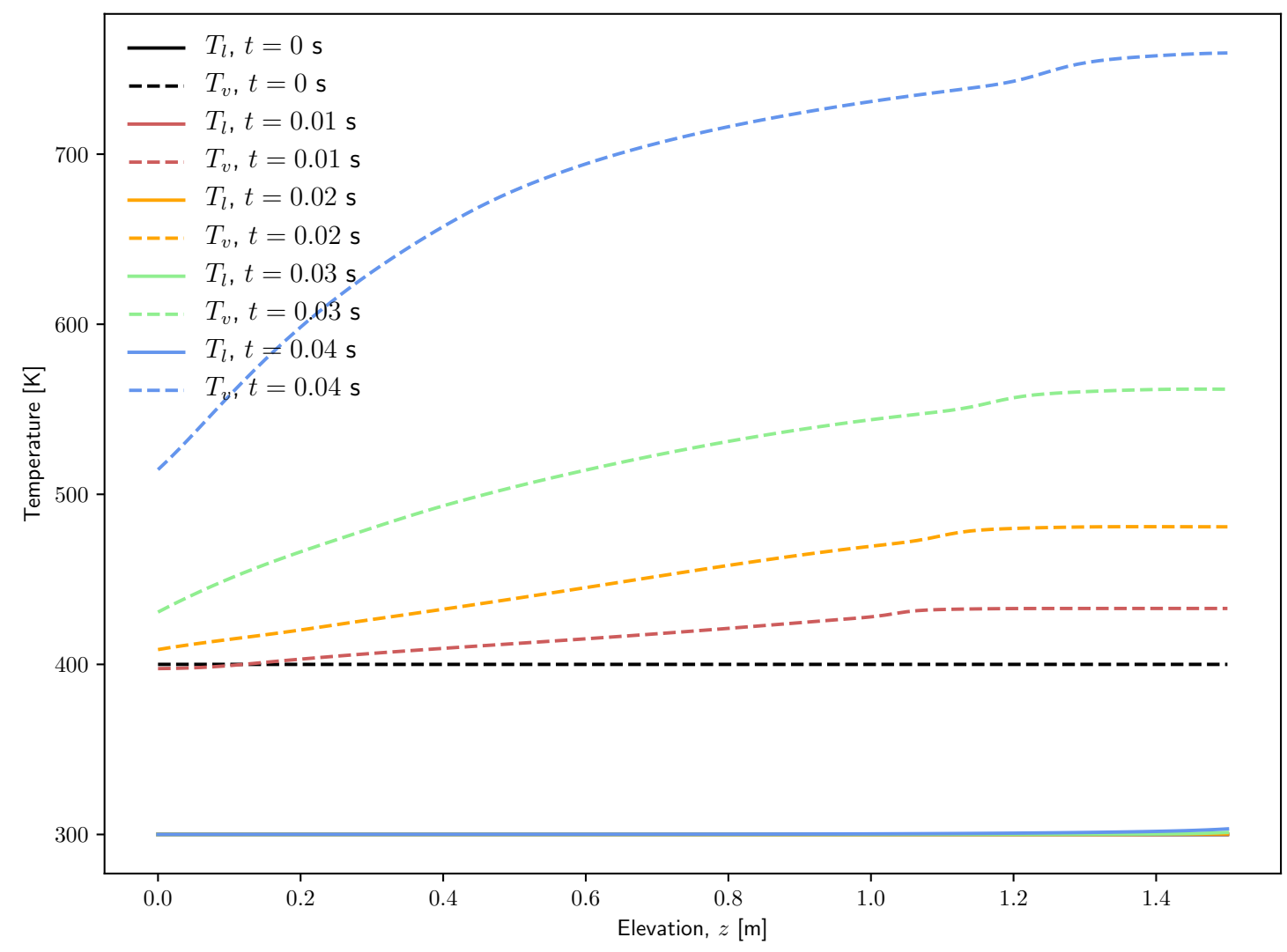

Figure 10. Temperatures at various times for Richard's Pipe 


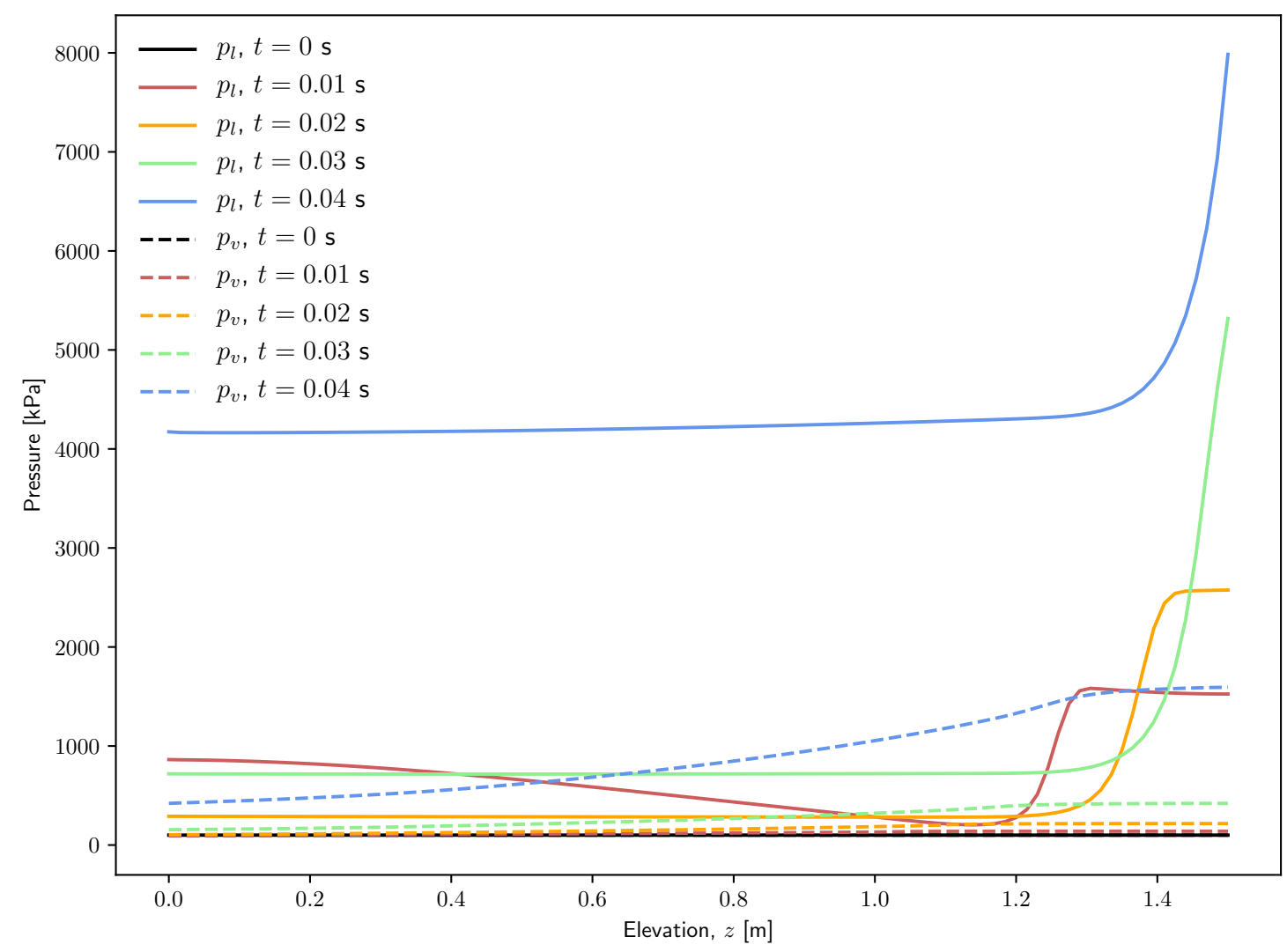

Figure 11. Pressures at various times for Richard's Pipe 


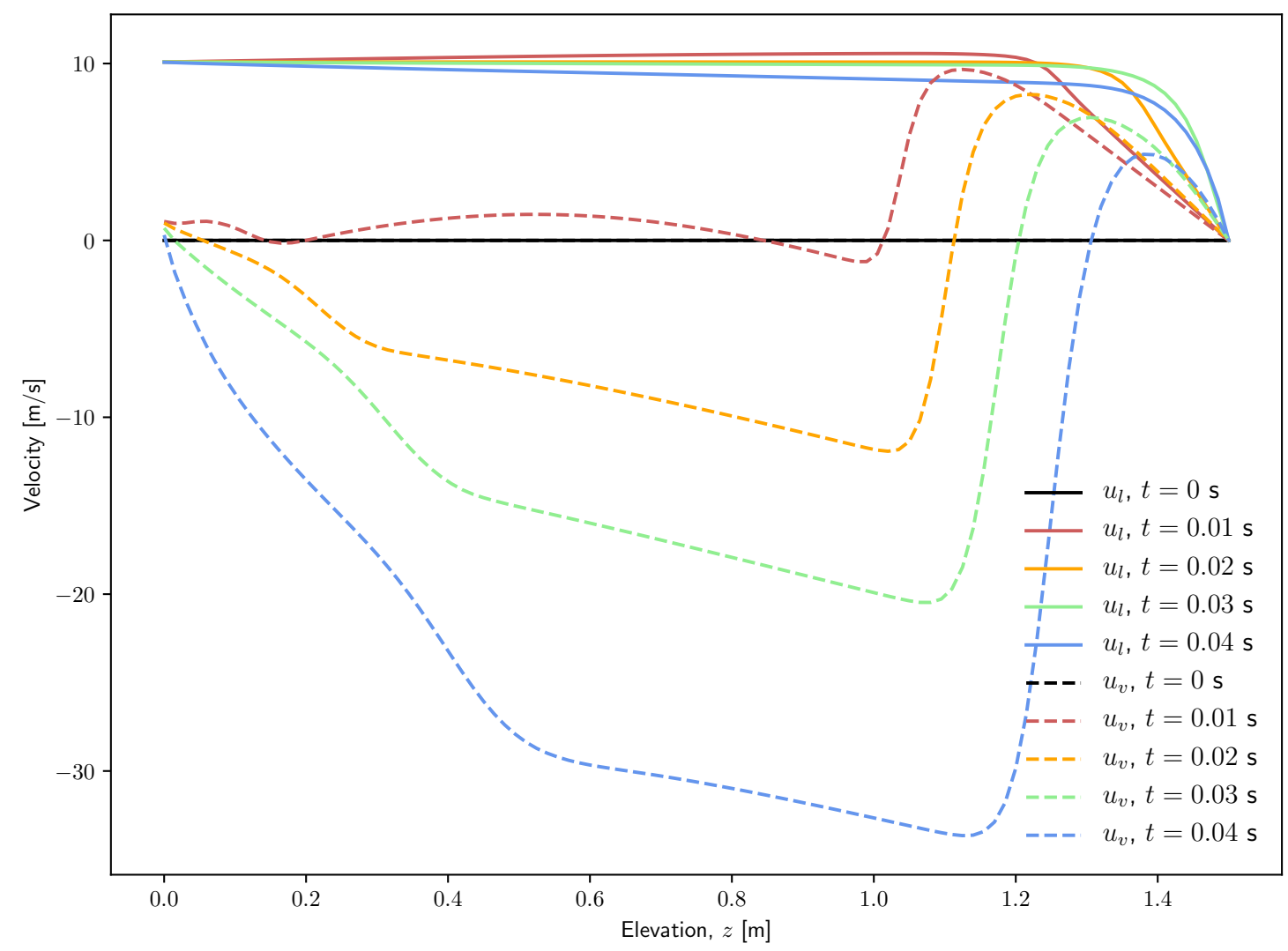

Figure 12. Velocities at various times for Richard's Pipe 


\section{Conclusions}

To model this type of transient more effectively, RELAP-7 needs to make a number of improvements. To start, the non-condensable gas capability needs quite a bit more work. This is a very new capability in RELAP-7, and its implementation is not fully completed. The underlying mixture model has undergone a few iterations in an attempt to increase the robustness of the solve in an implicit setting; some old mixture models would request evaluation of fluid properties of the mixture constituents in unphysical regions, due to the iterative nature of implicit solves. The current mixture model is believed to avoid, or at least mitigate, this issue, but is very young in its testing. Additionally, phase change rates have yet to be modified to account for the presence of non-condensable gases. Furthermore, the non-condensable gas capability needs to be extended to the recently implemented RDG spatial discretization, and for CG spatial discretization, stabilization methods need to be extended as well.

Run time was observed to be another big issue with these simulations; relatively small time steps were required, even though the time integrator used, BDF2, has excellent stability properties. The issue is that the nonlinear iteration (performed by Newton or PJFNK) can have convergence difficulties for larger time steps, due to a wide range of nonlinear physics. Up to a point, Jacobian improvements can improve convergence, and thus decrease time step size, but ultimately, the physics themselves are believed to be the main culprit. So perhaps simplifications in physics may yield smaller simulation times, but this theory has yet to be tested.

On the whole, these simulations have demonstrated RELAP-7's potential for simulating a transient such as boiling in a SERTTA chamber, and there are plenty of improvements that could be made to improve its capability further. 


\section{References}

[1] J. Ortensi, B. Baker, Y. Wang, S. Schunert, and M. DeHart, "Transient simulation of the Multi-SERTTA experiment with MAMMOTH," June 2017. 


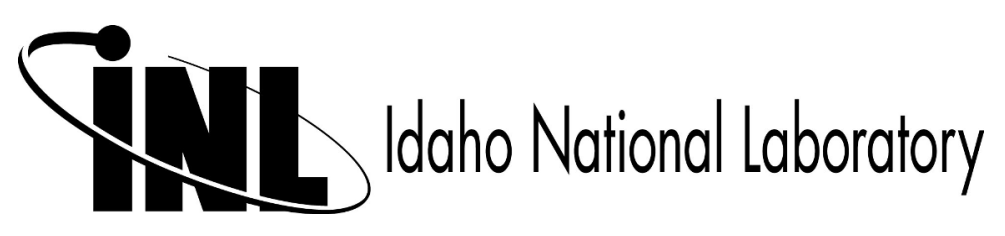

